Metallophysics and Advanced Technologies

металофіз. новітні технол.

Metallofiz. Noveishie Tekhnol.

2020 , vol. 42, No. 6, pp. 815-827

https://doi.org/10.15407/mfint.42.06.0815

Reprints available directly from the publisher
(C) 2020 G. V. Kurdyumov Institute for Metal Physics, National Academy of Sciences of Ukraine Published by license under

the G. V. Kurdyumov Institute for Metal PhysicsN.A.S. of Ukraine Publishers imprint. Printed in Ukraine.

PACS numbers: 61.46.-w, 62.25.Mn, 68.55.jm, 68.55.Nq, 81.07.Bc, 81.15.Cd

\title{
Effect of Energy Factors on the Structure and Substructure Characteristics of Hafnium Diboride Films Deposited by RF Magnetron Sputtering
}

\author{
A. A. Goncharov, A. V. Zykov", A. N. Yunda, \\ I. V. Shelest, and V. V. Buranich \\ Sumy State University, \\ 2 Rymsky-Korsakov Str., \\ UA-40007 Sumy, Ukraine \\ "V.N. Karazin Kharkiv National University, \\ 4 Svobody Sqr., \\ UA-61022 Kharkiv, Ukraine
}

In this paper, the influence of energy factors, such as the bias potential, current density, deposition rate, on the formation of the structure and substructure of hafnium diboride films deposited using RF magnetron sputtering is analysed. As shown, the structural changes from a quasi-amorphous to a nanocrystalline state with a growth texture occur due to changes in energy factors.

Key words: magnetron sputtering, deposition conditions, structure, substructure, hafnium diboride film.

В роботі проведено аналіз впливу енергетичних факторів, таких як потенціал зсуву, що подається на підкладку, густина йонного струму на підкладку і швидкість осадження, на формування структури та субструктури плівок диборида гафнію, отриманих ВЧ-магнетронним розпорошенням. Показано, що структурні зміни від квазиаморфного стану до нанокристалічного з текстурою зростання відбуваються внаслідок змін енергетичних факторів.

Corresponding author: Oleksandr Andriyovych Goncharov

E-mail: o.goncharov@mss.sudu.edu.ua

Citation: A. A. Goncharov, A. V. Zykov, A. N. Yunda, I. V. Shelest, and

V. V. Buranich, Effect of Energy Factors on the Structure and Substructure Characteristics of Hafnium Diboride Films Deposited by RF Magnetron Sputtering, Metallofiz. Noveishie Tekhnol., 42, No. 6: 815-827 (2020),

DOI: $10.15407 /$ mfint.42.06.0815. 
Ключові слова: магнетронне розпорошення, параметри осадження, структура, субструктура, плівка дибориду гафнію.

В работе проведен анализ влияния энергетических факторов, таких как потенциал смещения, подаваемый на подложку, плотность ионного тока на подложку и скорость осаждения, на формирование структуры и субструктуры плёнок диборида гафния, полученных ВЧ-магнетронным распылением. Показано, что структурные изменения от квазиаморфного состояния до нанокристаллического с текстурой роста происходят вследствие изменения энергетических факторов.

Ключевые слова: магнетронное распыление, параметры осаждения, структура, субструктура, плёнка диборида гафния.

(Received September 4, 2019; in final version, December 17, 2019)

\section{INTRODUCTION}

The problem of obtaining nanostructured materials based on transition metal diborides with predetermined physical-mechanical properties is highly relevant at the present time in connection with their use as protective coatings that have high thermal stability and durability. As common, PVD methods based on particle interaction processes in vacuum are used to obtain such coatings. One of these methods is RFmagnetron sputtering described in this article.

Analysis of the structural features of transition metal diboride coatings shows [1-2] that films can form in different structural states from amorphous-like to nanocrystalline with the growth texture (00.1). A distinctive feature of these films is that the structure changes from an amorphous-like to a nanocrystalline state are resulted in the changes in the composition B/TM from 1.4-1.6 to 2.3-2.4, and nanocrystallite size from 1 to $50 \mathrm{~nm}$, that accordingly leads to the change in their physico-mechanical characteristics.

The determining factor in the crystallization and formation of the film structural state is the energy delivered to growing surface [3,4]. It is known that the total energy [4,5] supplied to the coating during growth includes thermal, exothermic and radiation components, as well as kinetic energies of accelerated ions and neutral atoms bombarding the substrate.

Under the low-temperature plasma conditions, which take place in magnetron sputtering, the main contribution to the total energy delivered to the growing film is made by the thermal component (the energy delivered by substrate heating) and bombarding ions energy $E_{b i}=e\left(U_{P}-U_{S}\right)$, where $e$ is the elementary charge, $U_{P}$ and $U_{S}$ are the plasma and substrate potentials. Amount of $E_{b i}$ is considered as an 'internal' parameter of the magnetron sputtering system (MSS), which 
determine formation and growth of film structure. In addition to the energy of bombarding ions, the authors also include to 'internal' parameters the ratio of the flux of ions bombarding the substrate to the flux of neutral atoms that form the coating $\Phi_{i} / \Phi_{n}$. In work [6] the influence of these parameters on the structure formation of $\mathrm{TiB}_{2}$ and $\mathrm{TiN}$ films, deposited by means of two different DC MSS, was investigated.

The product of $E_{b i}$ and $\Phi_{i} / \Phi_{n}$ gives amount of energy, delivered to a film by bombarding ions per one deposited atom [7]. In works of other authors [8-10] the identical quantity is used as the 'internal' parameter the identical value-the energy of the bombarding ions per unit volume of the film or by the other words-energy density, that delivered to the growing film by positive ions $E_{b i}$, which value is determined by the following formula:

$$
E_{b i}=\left(U_{P}-U_{S}\right) j_{S} / a_{D},
$$

where $a_{D}=h / t$ is the deposition rate, here $h$ is the film thickness, $t$ is the deposition time.

It is obvious that the energy density delivered to the growing film by bombarding ions is determined by the following parameters: average plasma potential $U_{P}$ and substrate bias $U_{S}$, ion current density $j_{S}$ on a substrate; deposition rate $a_{D}$.

The plasma potential depends on ratio of the target area to the total area of the remaining surfaces in contact with the discharge. In addition to the geometry of the discharge, the plasma potential $U_{P}$ is strongly depended on the power pumped into discharge. The negative bias applied to the substrate does not affect the plasma potential, whereas the positively biased electrode causes an increase in the plasma potential [11]. Ion current density on the substrate $j_{S}$ is function $j_{S}=f\left(U_{S}\right)$ determined by current-voltage characteristics on the substrate and also depends on MSS parameters. Deposition rate $a_{D}$ depends on the power supplied into discharge, the target-to-substrate distance, working gas pressure and the substrate bias $U_{S}$. Thus, $E_{b i}$ quantity determines the set of 'external' and 'internal' factors of the MSS and depends on characteristics of applied MSS, respectively.

The main purpose of this study is to investigate the energy factors effect (bias potential, the ion current density and the deposition rate) on the composition, structure, and substructure characteristics of hafnium diboride films.

\section{EXPERIMENTAL SETUP}

A horizontal RF-sputtering system based on planar magnetron was used in this work for $\mathrm{HfB}_{2}$ films deposition. The system is designed to use standard round targets of 120-125 $\mathrm{mm}$ diameter and thickness up 
to $10 \mathrm{~mm}$. The schematic diagram of the sputtering unit is shown in Fig. 1. The magnetic field of the magnetron with intensity about $4 \times 10^{3}$ $\mathrm{A} / \mathrm{m}$ on the surface of the target is created by a set of annular permanent magnets $(\mathrm{Co}-\mathrm{Sm})$ with a steel polarity. By RF power source is used $13.56 \mathrm{MHz}$ generator with regulated power up to $1 \mathrm{~kW}$, connected to the load by means of a matching device, which is an L-circuit of tunable reactive elements, and a blocking capacitor $C_{b}$, providing the appearance of negative self-bias on the target (Fig. 1).

The substrate holder is electrically insulated from chamber walls by ceramic insulators and designed for the plate substrates fastening. The DC-voltage source is connected to the substrate holder through the high-pass filter, allowing to vary the substrate bias from $-\mathbf{1 0 0}$ to $+\mathbf{1 0 0}$ $\mathrm{V}$. The values of the bias potentials and ion currents on the target and substrate are monitored by pointer instruments (measurement error $\pm 5 \%$ ). The samples are heated by means of tungsten glowing spiral of 2 $\mathrm{mm}$ diameter. The chromel-alumel thermocouple provides temperature control up to $1100 \mathrm{~K}$.

Sputtering of the hot-sintered target $\mathrm{HfB}_{2}$ was carried out in $\mathrm{Ar}^{+}$ plasma. Hafnium diboride coatings were deposited on stainless steel substrates $\left(20 \times 10 \times 3 \mathrm{~mm}^{3}\right)$ pre-polished to the roughness $R_{a}=0.25 \mu \mathrm{m}$.



Fig. 1. The scheme of the magnetron sputtering system: 1-unbalanced magnetron; 2-anode; 3-target; 4-substrate holder; 5-thermocouple; 6substrate holder heater; 7-substrate holder heater's power supply; 8insulator; 9 -temperature sensor; 10 -indicator of the substrate bias; 11 the indicator of ion current through the substrate holder; $12-$ DC power supply for the application of substrate bias. 
The pressure of the residual gases in the chamber before deposition was $(2-3) \cdot 10^{-3} \mathrm{~Pa}$. The working gas pressure of $0.87 \mathrm{~Pa}, \mathrm{RF}$-generator power of $500 \mathrm{~W}$ and substrate temperature of $\cong 400^{\circ} \mathrm{C}$ were maintained during deposition. The substrate bias was varied from +50 to $-50 \mathrm{~V}$ with the increments of $25 \mathrm{~V}$. Target-to-substrate distance $d_{T-S}$ was $60 \mathrm{~mm}$. The deposition time was $60 \mathrm{~min}$ for all modes. The films thickness was measured by the method of multiple-beam interferometry using a MII4 instrument and amounted $0.8-1.8 \mu \mathrm{m}$.

$\mathrm{X}$-ray diffraction researches of the material structure were carried out on an automated diffractometer DRON-3. The $\mathrm{Cu} K_{\alpha}$ radiation (wavelength $0.154 \mathrm{~nm}$ ) and the Bragg-Brentano focusing method $\theta-2 \theta$ (20-Bragg angle) were used. The values of current and voltage of the $\mathrm{X}$-ray tube were $20 \mathrm{~mA}$ and $40 \mathrm{kV}$. Sampling carried out with horizontal slits of $4 \mathrm{~mm}$ on the tube and of $1 \mathrm{~mm}$ on the detector in continuous registration mode with a rate of $1 \% / \mathrm{min}$ in $2 \theta$ angle range from $25^{\circ}$ to $60^{\circ}$.

Mechanical tests were carried out on a Nano Indentor II nanohardness tester (MTS System Co.) equipped with a Berkovich indentor. Three measurements of the load and displacement were performed each second. The measurement error was $\pm 0.04 \mathrm{~nm}$ for the indentor displacement and $\pm 75 \mathrm{nN}$ for the load applied to the indentor. To achieve the accuracy of the results of measuring loading-unloading, we carried out ten measurements for each specimen; the measurement error was $5-10 \%$ for each specimen.

\section{RESULTS}

\subsection{Current-Voltage Characteristics of Deposition Process}

The relationship between the substrate ion current density $j_{S}$ and bias potential $U_{S}$ is determined by the current-voltage characteristics measured on substrate.

The ion saturation current density on the substrate is about 2.5 $\mathrm{mA} / \mathrm{cm}^{2}$ (see Fig. 2). The electron current density increases almost linearly up to $15 \mathrm{~mA} / \mathrm{cm}^{2}$ at $+100 \mathrm{~V}$.

It should be noted that the substrate current-voltage characteristics coincide qualitatively with those obtained in works $[9,12,13]$ at DC and RF magnetron sputtering.

However, there is a discrepancy in the quantitative values of the plasma potentials. A significant difference is that the plasma potential in a conventional $\mathrm{RF}$ discharge significantly higher than the plasma potential in DC discharge $(+20 \mathrm{~V}$ and $+4 \mathrm{~V}$, respectively [11]). Similar results are presented in work [12]: $U_{P}=+15 \mathrm{~V}$ for $\mathrm{RF}$ discharge and +3 $\mathrm{V}$ for DC. Since the properties of a pulsed discharge are identical to those of an RF discharge, the pulsed discharge also has negative and 
positive periods, and the same ratio is observed for the plasma potential of the pulsed and DC discharges [9]: $U_{P}=+28 \mathrm{~V}$ and $U_{P}=+5 \mathrm{~V}$ for the pulse discharge and DC discharge, respectively. This occurs due to combination of the factors such as the chamber walls material, pressure and purity of the working volume, geometric dimensions of the MSS, type of magnetron and its power supply [9].

\subsection{Phase Analysis and Texture}

The diffraction patterns of hafnium diboride films deposited on the stainless steel and single-crystal Si (111) substrates at different values of substrate bias are shown in Figs. 3, 4. For comparison, the diffraction pattern of sintered $\mathrm{HfB}_{2}$ powder target is shown in Fig. 5.

The X-ray diffraction patterns are characterized by the presence of clear reflexes $(001),(10.0),(10.1),(00.2)$ and $(10.2)$, which make it possible to identify the phase of $\mathrm{HfB}_{2}$ (structural type $\mathrm{AlB}_{2}$, space symmetry group $P 6 / \mathrm{mmm}$ ). In [14-16], the influence of the substrate structure, substrate temperature and structure bias on the formation and physico-mechanical characteristics of hafnium nanocrystalline films was studied. It is shown that the sign and magnitude of the applied bias potential to substrate makes the main energy contribution in film nanostructure formation. However, as shown in [14, 15], the energy of structure forming process essentially depends on magnetron sputtering system design, geometry, etc. Therefore, in this work, the influence of energy factors on the formation of hafnium diboride films

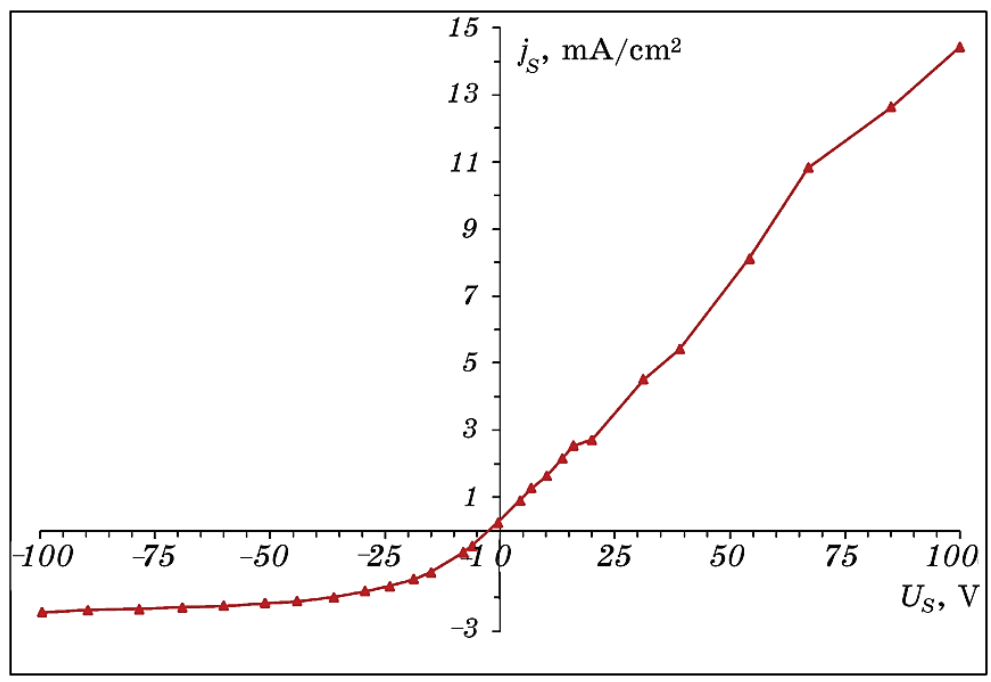

Fig. 2. $I-V$ characteristic measured on substrate. 
structure and substructural characteristics deposited on various substrates was investigated.

It is shown that nanocrystalline films formed with preferential growth texture in the plane (00.1). In this case, depending on the applied bias potential, hafnium diboride films with different degrees of texture are formed (Table 1).

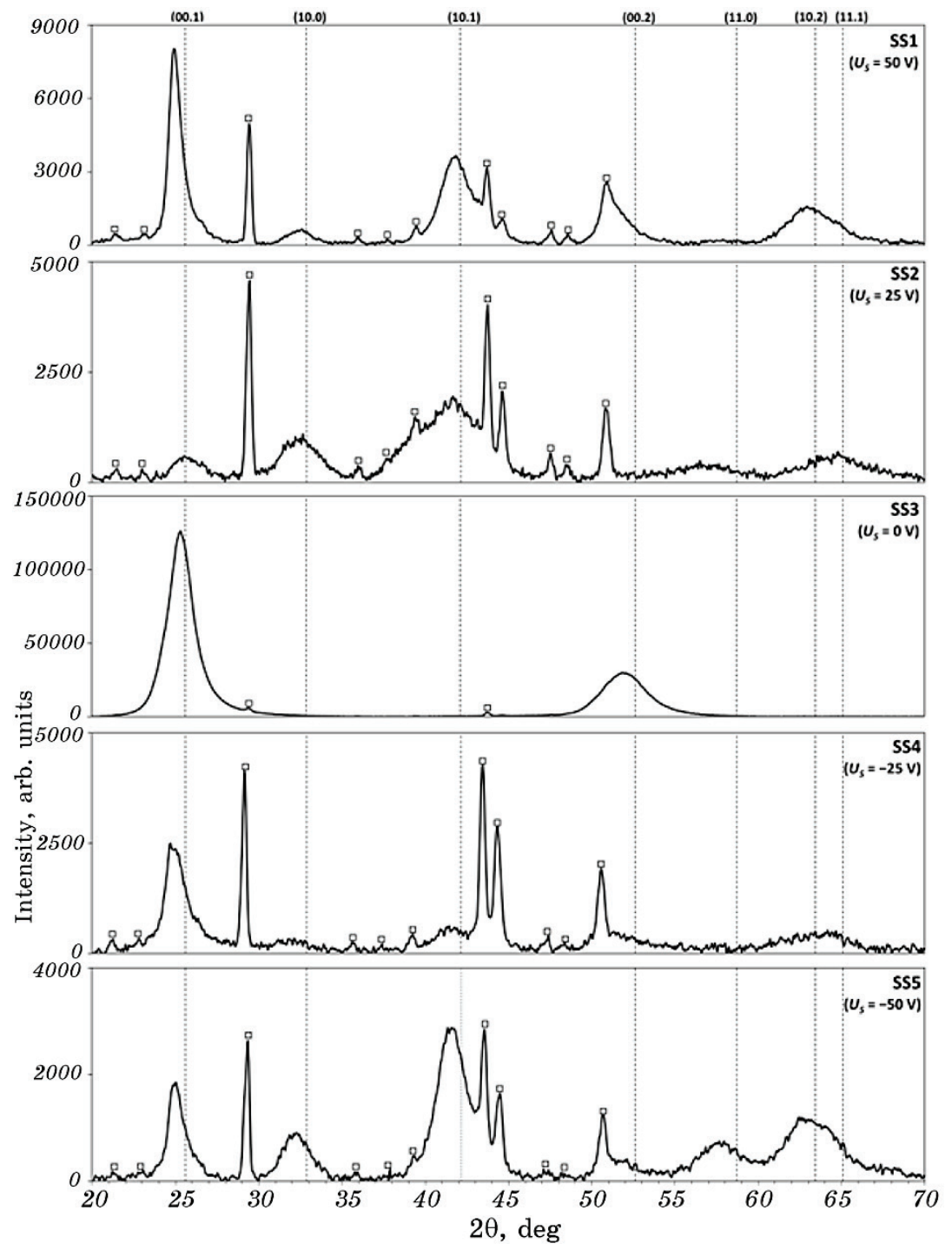

Fig. 3. Diffraction patterns of hafnium diboride films deposited on stainless steel substrates at different values of the substrate bias. The symbol ' $\mathrm{\prime}$ ' indicate the reflexes of the substrate. 
At grounded substrate holder, textured coatings with the most intense texture (00.1) are formed at the highest deposition rate (for this experiment) $\cong 30 \mathrm{~nm} / \mathrm{min}$ (Fig. 3,a). The diffraction pattern occurs the main diffraction peaks $(00.1)$ and $(00.2)$, diffraction peaks $\alpha$-Fe $\left(2 \theta=44^{\circ}\right)$ practically disappear. Texture of greater extent is formed on the $\mathrm{Si}(111)$ substrates, although the intensity of the diffraction peak is almost 10 times less than steel, and the deposition rate is about 2 times less.

The supply of a negative bias potential of $-25 \mathrm{~V}$ leads to a decrease in the growth texture of the (00.1), and appearance of (10.0), (10.1),

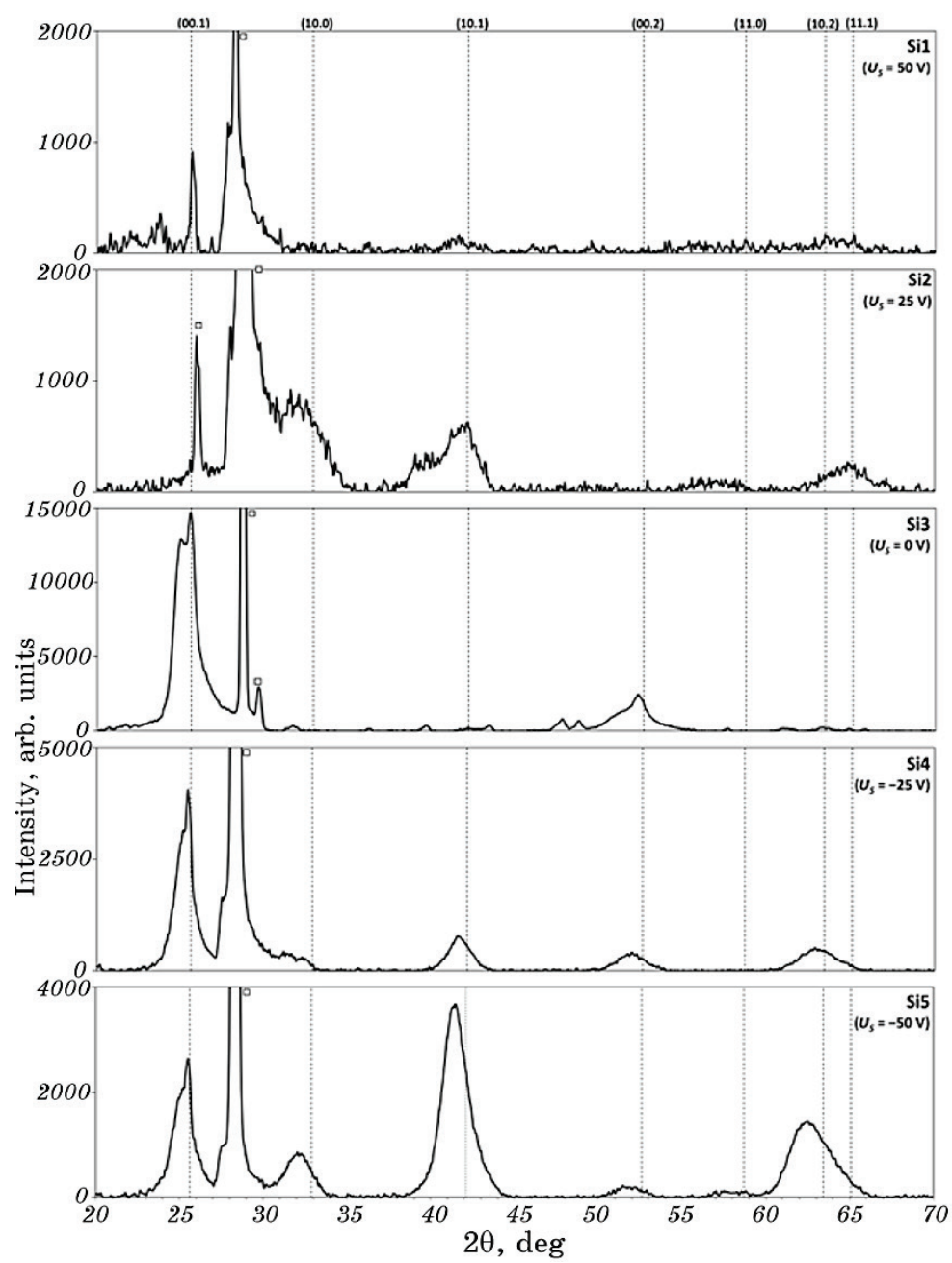

Fig. 4. Diffraction patterns of hafnium diboride films deposited on $\operatorname{Si}(111)$ substrates at different values of the substrate bias. The symbol ' $\mathrm{a}$ ' indicate the reflexes of the substrate. 
(11.1), (10.2) diffraction peaks. The substrate peaks are more pronounced, which indicates lower coating thicknesses due to lower growth rates of 18 and $13.5 \mathrm{~nm} / \mathrm{min}$ on steel and silicon, respectively. The change in the structural state of the film at a bias potential of -25 $\mathrm{V}$ due to ion bombardment of the surface formed, the ion current density was $1.7 \mathrm{~mA} / \mathrm{cm}^{2}$.

A further increase in the negative bias to $-50 \mathrm{~V}$ results an insignificant increase in the ion current density to $2.2 \mathrm{~mA} / \mathrm{cm}^{2}$, which indicates that the current starts to saturate. There is a change in the structural state and appearance of the texture (10.1), which was accompanied by a decrease in the intensity of the peak (00.1) and decrease in its degree of texture, as well as an increase of all main diffraction peaks intensities (10.0), (10.1), (11.1), (10.2), corresponding to the $\mathrm{HfB}_{2}$ phase. The growth rate was approximately the same on both substrates $(\cong 20$ $\mathrm{nm} / \mathrm{min}$ ). The features of structure formation correlate with energy factors $U_{S}, j_{S}$ and $a_{D}$ according to the presented measurements. Less significant structural changes occur when a positive bias potential +25 $\mathrm{V}$ applied to the substrate holder. Nanocrystalline films are formed with a growth texture normal to the $(00.1)$ plane, diffraction peaks (10.0), (10.1), (10.2) also presented. There is a decrease in texture intensity (00.1) in comparison with strongly textured films and a decrease in the growth rate up to $\cong 24 \mathrm{~nm} / \mathrm{min}$. An increase in the bias potential up to $+50 \mathrm{~V}$ does not lead to the structure change, the texture

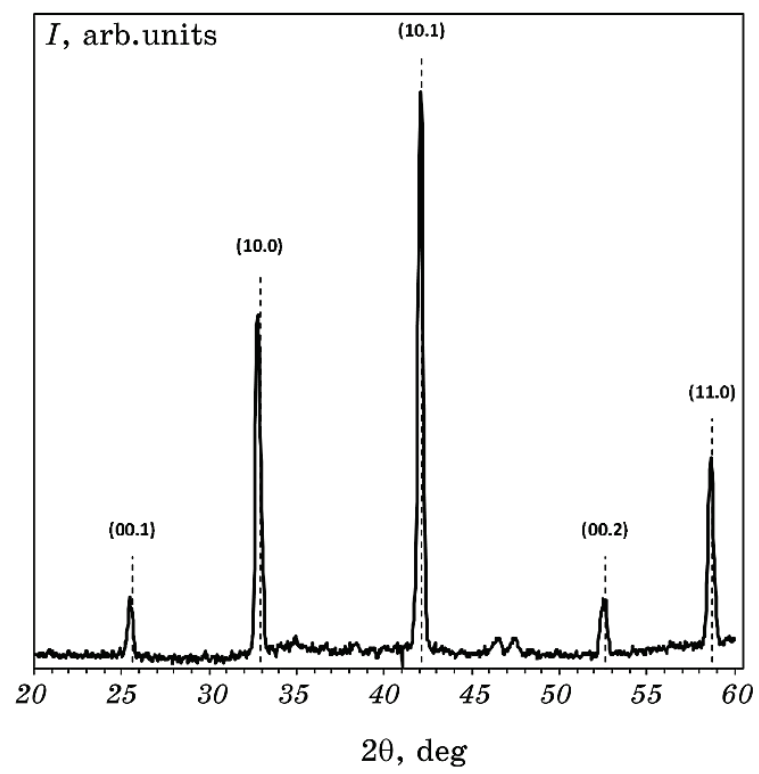

Fig. 5. Diffraction pattern of sintered $\mathrm{HfB}_{2}$ powder target. 
TABLE 1. Structural and substructural characteristics of hafnium diboride coatings deposited on SS and Si substrates at different modes.

\begin{tabular}{|c|c|c|c|c|c|c|c|c|c|c|}
\hline \multirow{2}{*}{ Substrate } & \multicolumn{3}{|c|}{ Deposition conditions } & \multicolumn{2}{|c|}{$\begin{array}{c}\text { Texture peak } \\
\text { (0001) properties }\end{array}$} & \multicolumn{5}{|c|}{ Substructural characteristics } \\
\hline & $\begin{array}{c}U_{S}, \\
\mathrm{~V}\end{array}$ & $\begin{array}{c}j_{S}, \\
\mathrm{~mA} / \mathrm{cm}^{2}\end{array}$ & $\begin{array}{c}a_{D} \\
\mathrm{~nm} / \min \end{array}$ & $\begin{array}{c}\text { FWHM, } \\
\mathrm{rad}\end{array}$ & $\begin{array}{l}\text { Intensity, } \\
\text { arb. units }\end{array}$ & $\begin{array}{c}a, \AA \\
\left(3.1424^{*}\right)\end{array}$ & $\begin{array}{c}c, \AA \\
\left(3.476^{*}\right)\end{array}$ & $\begin{array}{c}c / a \\
\left(1.106^{*}\right)\end{array}$ & \begin{tabular}{|c|}
$D$, \\
$\mathrm{nm}$
\end{tabular} & $<\varepsilon>$ \\
\hline SS & 50 & -7.4 & 18.5 & 0.01487 & 8000 & 3.1646 & 3.5420 & 1.119 & 10.8 & 0.0210 \\
\hline SS & 25 & -3.5 & 24 & 0.04156 & 550 & 3.1817 & 3.5180 & 1.106 & 3.6 & 0.0227 \\
\hline SS & 0 & 0.3 & 30 & 0.03062 & 126500 & $\boldsymbol{d}_{001}=3$ & 3.5133 & - & 9.1 & 0.0281 \\
\hline SS & -25 & 1.7 & 18 & 0.02625 & 2370 & 3.2018 & 3.5390 & 1.105 & 5.8 & 0.0296 \\
\hline SS & -50 & 2.2 & 20 & 0.01969 & 1850 & 3.1926 & 3.5358 & 1.107 & 7.9 & 0.0329 \\
\hline $\operatorname{Si}(111)$ & 50 & -7.4 & 15.5 & \multicolumn{7}{|c|}{ Texture was not detected } \\
\hline $\operatorname{Si}(111)$ & 25 & -3.5 & 23.5 & 0.02625 & 200 & 3.2057 & 3.4448 & 1.075 & 6.9 & 0.0150 \\
\hline $\operatorname{Si}(111)$ & 0 & 0.3 & 16.5 & 0.02734 & 12500 & $\boldsymbol{d}_{001}=3$ & 3.5215 & - & 10.3 & 0.0251 \\
\hline $\operatorname{Si}(111)$ & -25 & 1.7 & 13.5 & 0.02406 & 3100 & 3.1905 & 3.5135 & 1.101 & 7.7 & 0.0148 \\
\hline $\operatorname{Si}(111)$ & -50 & 2.2 & 19.5 & 0.02625 & 2077 & 3.2076 & 3.5207 & 1.098 & 6.2 & 0.0097 \\
\hline
\end{tabular}

"-Database of JCPDS.

intensity decreases insignificantly relatively, and the degree remains unchanged within the error margin.

According to the analysis of substructural characteristics, the lattice parameters evaluated by means of methods exhaustively described in [16] were varied within $a \cong 3.16-3.21 \AA$ (table value is $3.14 \AA$ ), $c \cong 3.44-3.54 \AA$ (table value is $3.47 \AA$ ). The greatest increase in lattice parameters observed for strongly textured samples obtained with a zero potential on the substrate holder and films obtained at a negative bias potential of $-25 \mathrm{~V}$. There also some differences in lattice parameters for the films obtained on different substrates, but they are not essential.

Nanocrystallites' sizes calculations by the Scherrer formula showed that for all synthesized films it is $\cong 3.6-10.8 \mathrm{~nm}$, which contradicts earlier studies of hafnium diboride films [14, 15]. Films microdeformation is also significantly overestimated compared to those what previously obtained [14].

\section{DISCUSSION OF RESULTS}

Studies have shown that in case of RF magnetron sputtering at the substrate bias from +50 to $-50 \mathrm{~V}$ and the ion (electron) current density according to the VCC, the nanocrystalline hafnium diboride films was 
formed. All films inherent growth oriented normal to the plane (00.1). In this case the intensity of the texture and the substructural parameters are changed depending on the substrate bias. There are no significant structural differences between coatings obtained on different substrates.

Hafnium diboride films with the least strong growth texture normal to the (00.1) plane were obtained with a grounded substrate regime. At same time, as was shown in similar works on this subject (see below), films with a strong texture had the best physico-mechanical characteristics. In this case values of nanohardness and elastic modulus evaluated by analysing the curve of indentor unloading using the Oliver and Farr method [17] were $H=45.8 \pm 2.1 \mathrm{GPa}$ and $E=306 \pm 19 \mathrm{GPa}$.

In our previous studies $[18,19]$, the formation of the strong texture (0.01) of hafnium diboride films deposited by means of RF-magnetron sputtering was occurred at substrate bias of $+50 \mathrm{~V}$ and the substrate temperature of $500^{\circ} \mathrm{C}$. Thus obtained films had the best physical and mechanical characteristics. Nanohardness and elastic modulus of the films deposited on tungsten carbide substrates were $H=44 \pm 3.7 \mathrm{GPa}$ and $E=469 \pm 18 \mathrm{GPa}$, respectively, and on the stainless steel substrates $-H=41 \mathrm{GPa}$ and $E=396 \mathrm{GPa}$. However, in this case, a different configuration was used, which probably leads to a change in the energy parameters (see Table 2).

The analysis shows that parameters determining the total bulk energy density delivered to the growing film (or the total energy per one deposited atom) during the deposition of transition metals diboride nanocrystalline films having a predominant growth texture of normal to $(00.1)$ plane and possessing the best physical-mechanical characteristics substantially depend on the parameters of the MSS. Knowledge (control) of the energy density, which is necessary to obtain films with

TABLE 2. Deposition parameters, structural and mechanical properties of $\mathrm{HfB}_{2}$ films.

\begin{tabular}{|c|c|c|c|c|c|c|c|c|c|c|c|c|}
\hline 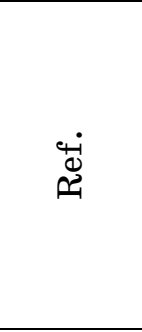 & 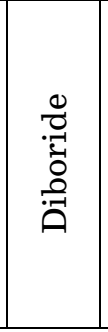 & 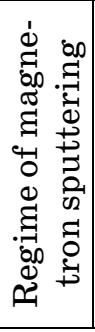 & 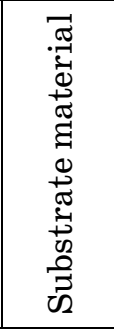 & 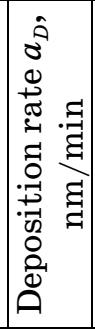 & 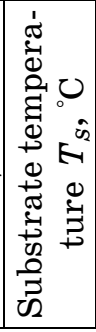 & 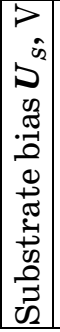 & 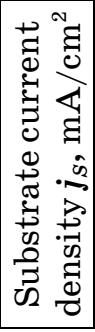 & 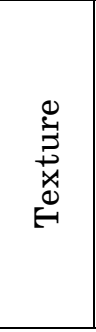 & 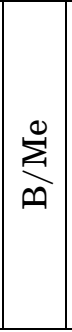 & 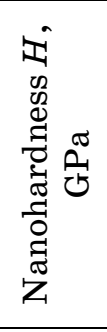 & 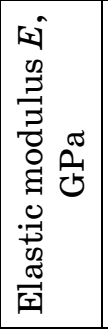 & 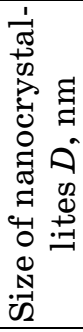 \\
\hline $\begin{array}{c}\text { Present } \\
\text { work }\end{array}$ & $\mathrm{HfB}_{2}$ & $\mathrm{RF}$ & $\begin{array}{l}\mathrm{SS}, \mathrm{Si} \\
(111)\end{array}$ & 30 & $\cong 400$ & 0 & 0.25 & 0001 & - & $\begin{array}{c}45.8 \pm \\
\pm 2.1\end{array}$ & $\begin{array}{c}306 \pm \\
\pm 19\end{array}$ & 5.4 \\
\hline $\begin{array}{c}{[15],} \\
{[17]}\end{array}$ & $\mathrm{HfB}_{2}$ & $\mathrm{RF}$ & SS & 22 & 100 & 50 & 0 & 0001 & 2.4 & $\begin{array}{c}44.0 \pm \\
\pm 0.8\end{array}$ & $\begin{array}{c}469 \pm \\
\pm 18\end{array}$ & 20 \\
\hline
\end{tabular}


specified properties, namely, its dependence on the MSS parameters, will allow to reproduce these coatings using MSS of any configuration.

\section{CONCLUSIONS}

In present work, the hafnium diboride films were deposited by RF magnetron sputtering on stainless steel and silicon $\mathrm{Si}(111)$ substrates. The study of the influence of RF magnetron sputtering energy factors on the formation structural and substructural characteristics of $\mathrm{HfB}_{2}$ films showed that films with the highest growth texture degree normal to $(00.1)$ plane were formed at the following parameters determining the energy density delivered to the growing film: $a_{D}=30 \mathrm{~nm} / \mathrm{min}, T_{S}=$ $=400^{\circ} \mathrm{C}, U_{S}=0 \mathrm{~V}, j_{S}=0.25 \mathrm{~mA} / \mathrm{cm}^{2}$.

\section{ACKNOWLEDGMENTS}

This work was performed within the framework of the budget program No. $0117 \mathrm{U} 002247$ 'Technological bases of the synthesis of nanostructured, nanocomposite and multi-layer coatings of refractory compounds for application in mechanical engineering'.

\section{REFERENCES}

1. A. A. Goncharov, S. N. Dub, A.V. Agulov, and V. V. Petukhov, J. Superhard Mater., 37, No. 6: 422 (2015).

2. A. A. Goncharov, A. N. Yunda, H. Komsta, and Rogalski, Acta Phys. Pol. A, 132, No. 2: 270 (2017).

3. M. Mikula, B. Grančič, T. Roch, T. Plecenik, I. Vávra, E. Dobročka, A. Šatka, V. Buršíková, M. Držík, M. Zahoran, A. Plecenik, and Kúš, Vacuum, 85, No. 9: 866 (2011)

4. J. Musil, J. Šícha, D. Heřman, and R. Čerstvý, J.Vac.Sci. Technol.A, 2, No. 4: 666 (2007).

5. J. A. Thornton, J.Vac.Sci. Technol., 11, No. 4: 666 (1974).

6. C. Mitterer, P. H. Mayrhofer, E. Kelesoglu, R. Wiedemann, and H. Oettel, Metallkd., 90, No. 8: 602 (1999).

7. I. Petrov, P. B. Barna, L. Hultman, and J. E. Greene, J.Vac. Sci. Technol.A, 21, No. 5: S117 (2003).

8. J. Musil, M. Jaroš, R. Čerstvý, and S. Haviar, J.Vac. Sci. Technol.A, 35, No. 2: 020601 (2017).

9. J. Musil and M. Jaroš, J.Vac. Sci. Technol. A, 35, No. 6: 060605 (2017).

10. J. Musil and S. Kadlec, Vacuum, 40, No. 50: 435 (1990).

11. J. W. Coburn and E. Kay, J.Appl. Phys., 43, No. 12: 4965 (1972).

12. B. Window and N. Savvides, J.Vac. Sci. Technol.A, 4, No. 2: 196 (1986).

13. K. Ellmer, J.Phys. D: Appl. Phys., 33, No. 4: R17 (2000).

14. A. A. Goncharov, V. A. Konovalov, G. K. Volkova, and V. A. Stupak, Phys. Met. Metallogr., 108, No. 4: 368 (2009). 
15. A. V. Agulov, A. A. Goncharov, V. A. Stupak, and V. V. Petukhov, Inorg. Mater., 50, No. 5: 460 (2014).

16. S. S. Gorelik, Yu. A. Skakov, and L. N. Rastorguev, Rentgenograficheskiy $i$ Elektronno-Opticheskiy Analiz [X-Ray Diffraction and Electron-Optical Analysis] (Moscow: MISIS: 2002) (in Russian).

17. W. C. Oliver and G. M. Pharr, J. Mater. Res., 7, No. 6: 1564 (1992).

18. A. A. Goncharov, S. N. Dub, and A. V. Agulov, Phys. Met. Metallogr., 14, No. 1: 95 (2013).

19. A. A. Goncharov, Phys. Met. Metallogr., 111, No. 3: 314 (2011). 